\title{
Philosophical Review of State's Sovereignty in The Sea On Foreign Cross-Ship Rights in Indonesia Waters
}

\begin{abstract}
The purpose of this research is to find out the statutory arrangements and philosophical review of state sovereignty related to foreign ship rights in the waters of the Indonesian Archipelago. This research is a normative legal research with a statutory approach. The analytical technique used is the analytic critique analysis technique in the form of a critical interpretation technique for legal materials, especially legal materials. The results show that in relation to PP No. 37/2002, the determination of the archipelagic sea lane should refer to Law No. 6/1996 and Article 53 of the United Nations Convention on the Law of the Sea (UNCLOS) 1982. In a philosophical review of the ontology aspects of sovereignty as the highest authority from a country in international law has experienced a shift. The highest power has shifted to a more limited direction, namely only within the national borders, while to get out of national borders is given and limited by international law. The epistemological aspect of state sovereignty in the archipelago waters is the same as in the territorial sea, that is, it cannot apply absolute sovereignty as in land area or in the air. Determination of the Indonesian Archipelagic Sea Lane (ALKI) will partly complicate the supervision of foreign vessels in unspecified sea lanes. This raises vulnerability for the sovereignty of the Indonesian state. The axiological aspect of state sovereignty is to bring benefits to create order and legal certainty related to the issue of the rights of foreign ships and aircraft crossing over vast waters based on the rights of archipelagic sea lanes crossing. In the perspective of the country's sovereignty especially the sovereignty of the state at sea, the determination of the right of passage for foreign vessels in the ALKI must guarantee territorial integrity and aim at protecting the wealth of the Indonesian state as an archipelago, according to the values contained in the 1957 Djuanda Declaration.
\end{abstract}

Bambang Wahyudi ${ }^{1}$, I Nyoman Nurjaya ${ }^{2}$, Prija Djatmika ${ }^{3}$, Dhiana Puspitawati ${ }^{4}$

1. $\mathrm{PhD}$. Candidate at Faculty of Law, Brawijaya University, Indonesia

2. Professor at Faculty of Law, Brawijaya University, Indonesia

3. Lecturer at Faculty of Law, Brawijaya University, Indonesia

4. Lecturer at Faculty of Law, Brawijaya University, Indonesia

Keywords: Philosophical review, Right of Pass, Foreign Ships, Waters, Indonesian Archipelagic Sea Pathways

(ALKI).

DOI: $10.7176 / J L P G / 92-26$

Publication date: December $31^{\text {st }} 2019$

\section{Introduction}

At the time of its independence in 1945, Indonesia's territorial waters still used the Territorial Sea Ordinance and the Maritime Environment (Territoriale Zee en Maritieme Kringen Ordonnantie) 1939. ${ }^{1}$ Physically the Indonesian archipelago is still fragmented by oceans with a territorial sea width of only 3 nautical miles. By 1957 the territorial sea width as far as 3 nautical miles was no longer sufficient to ensure the best interests of the people. ${ }^{2}$ As long as the waters between the Indonesian islands are still considered as the high seas, during this time foreign ships can legally enter the waters. So the Government of the Republic of Indonesia on December 13, 1957 announced a statement (declaration) regarding territorial waters, in the form of a Government Announcement concerning Indonesian Water Areas, which contained: ${ }^{3}$

".....that all waters around, between and connecting islands that are included in the mainland of the Republic of Indonesia, irrespective of the extent or width are reasonable parts of the mainland territory of the Republic of Indonesia and as such are part of the national waters below absolute sovereignty than the state of the Republic of Indonesia."

Since the announcement of the declaration, the Government of Indonesia has continued to fight for the conception of archipelagic state law to be accepted and recognized by the international community, one of which

\footnotetext{
${ }^{1}$ Etty R. Agoes. Konvensi Hukum Laut 1982, Masalah Pengaturan Hak Lintas Kapal Asing. (Bandung: Abardin, 1991), p. 156.

${ }^{2}$ Ibid. The interests of the people include: defense, national safety against interference/attacks from outside; supervision of the entry and exit of foreigners; implementing fiscal regulations; health, fisheries and mining interests.

${ }^{3}$ Mochtar Kusumaatmadja. Hukum Laut Internasional. (Bandung: Bina Cipta, 1986), p. 188.
} 
is to provide a legal basis in the Indonesian constitutional system in the form of Law Number 4 Prp of 1960 concerning Indonesian Waters. The law changes the way of determining Indonesian seas from a low water line or low water line to a $12 \mathrm{NM}$ wide sea area measured from a straight baseline drawn from end to end. The sea contained between the islands contained in the straight baseline is no longer a free sea, but has been turned into the waters of the archipelago and inland waters under Indonesian sovereignty. ${ }^{1}$

Based on the measurement method, then in the territorial waters of the Archipelago with an area of 3,110,000 square $\mathrm{km}$ there are approximately 17,504 islands which are under the sovereignty of the Republic of Indonesia, 16,056 of which have been submitted to the United Nations. ${ }^{2}$ Indonesian politics in international sea law starting with the 1957 Djuanda Declaration which was then followed by the enactment of the archipelago conception in 1960 and its implementing regulations were important contributions to the development of a new international law of the sea. ${ }^{3}$ With this one-sided action the conception of the archipelago has been lifted from the academic world into the reality of international life. The struggle has finally resulted in universal recognition, namely by accepting proposals from Indonesia, the Philippines, Fiji and Mauritius about the archipelagic state to be the principle and legal regime of the Archipelagic State in Chapter IV of the United Nations Convention on the Law of the Sea (United Nations Convention on the Law Of the Sea) 1982. ${ }^{4}$

This was welcomed by Indonesia by ratifying through Law Number 17 of 1985 concerning Ratification of the United Nations Convention on the Law of the Sea (UNCLOS) 1982. Indonesia was faced with a new task to transform its obligations from UNCLOS 1982 to national law in the form of implementing provisions the provisions of the new international law in the country. The 1982 Law of the Sea Law provides four types of passage rights for foreign vessels through a country's territorial waters, viz:

a. The right to cross peace, which can be enjoyed both in the territorial sea, the strait used for international shipping and the waters of the islands;

b. The right of transit, which is only recognized in the straits used for international shipping;

c. The right of archipelagic sea lane passage, which can only be enjoyed on sea lanes established by an archipelagic state in its archipelago waters; and

d. Special crossing rights for neighboring countries whose territories are separated due to the withdrawal of the archipelagic straight line.

In exercising the right of passage by foreign vessels, UNCLOS 1982 granted the coastal states the right to establish their laws and regulations. Indonesia as a coastal country has stipulated several laws and regulations, particularly related to the rights of foreign ships in the archipelagic sea lanes that are the focus of this research.

The addition of the territorial waters of the archipelago due to the concept of the island nation has legal consequences for Indonesia to accommodate international interests in its territorial waters, including determining the rights of archipelagic sea lanes passage for foreign ships passing through the territory the waters of the archipelago, according to the provisions of Article 53 paragraph (1) UNCLOS 1982. If Indonesia does not determine the intended sea lane, according to Article 53 paragraph (12), the rights of the archipelagic sea lane passage can be exercised through the route normally used for international shipping (routes normally used for international navigation). The provisions of Article 53 paragraph (12) for the Government of Indonesia can pose many risks in terms of national security and sovereignty, because the archipelagic sea lane crossings contain certain freedoms. ${ }^{5}$

Considering that Law Number 17 of 1985 regarding ratification of UNCLOS 1982 is considered not a law in a material (substantive) sense but only a procedural stipulation, the Government of Indonesia established Law

\footnotetext{
${ }^{1}$ Indien Winarwati. Konsep Negara Kepulauan, Perspektif Hukum Laut dan Penetapan Garis Batas Negara. (Malang: Setara Press, 2016), p.4-5.

${ }^{2}$ Memorandum of Understanding between the Geospatial Information Agency (BIG), the Navy's Oceanographic Hydro Center and the Maritime Coordinating Ministry on August 10, 2018.

${ }^{3}$ Mochtar Kusumaatmadja, Op. Cit., p. 205.

${ }^{4}$ Indien Winarwati, Op. Cit., p. 3.

${ }^{5}$ General Explanation Government Regulation of the Republic of Indonesia Number 37 of 2002 concerning the Rights and Obligations of Foreign Vessels and Aircraft in Implementing the Rights of the Islands Sea Channel Through the Specified Islands Sea Channel. Republic of Indonesia State Gazette Number 71 of 2002. Additional State Gazette Number 4210.
} 
Number 6 of 1996 as a follow-up to Law Number 17 of 1985 which transformed the KHL 1982 legal norms into national law. ${ }^{1}$ This law is a statutory regulation related to regional aspects. Article 18 and Article 19 of Law Number 6 of 1996 regulates the basic provisions concerning the rights of the archipelagic sea lanes for foreign vessels, which are the articles as a transformation or application of Article 53 KHL 1982. Article 18 paragraph (3) stipulates that the provisions more information about the rights and obligations of foreign ships and aircraft implementing the rights of the archipelagic sea lane passage regulated by Government Regulation (PP).

After submitting a proposal to the International Maritime Organization (IMO) and then being approved as a partial designation, ${ }^{2}$ The Indonesian government then stipulated the Indonesian Archipelagic Sea Pathways (ALKI) in PP No. 37 of 2002, and is a legislative regulation for delegates from Law No. 6 of 1996 concerning Indonesian Waters. Based on Article 11 of the PP, Indonesia stipulates 3 (three) North-South Island archipelagic sea lanes.

The right of archipelagic sea lane passage is one of the new types of transect rights introduced in UNCLOS 1982. However, there are only 6 (six) articles, namely Articles 39, 40, 42, 44 which apply mutatis mutandis, ${ }^{3}$ and Articles 53 and 54 of UNCLOS 1982 governing it, and there are no other international guidelines or laws governing this right of passage. Until now, only 19 of Indonesia have been classified as archipelagic states that have established archipelagic sea lanes. ${ }^{4}$

Therefore there are many legal issues related to the provisions contained in the PP in question. One of them is that Indonesia did not mention that the determination of three ALKI North-South routes as partial or full, while IMO was declared as a full designation ALKI or the designation was included in the category of partial determination, ${ }^{5}$ because Indonesia did not set the East-West sea route from the Arafuru Sea to the Java SeaKarimata Strait and vice versa. Determination of archipelagic sea lanes should be determined based on Law Number 6 of 1996 concerning Indonesian Waters, particularly in Article 18 paragraph (1) which states that: ${ }^{6}$

"(1)... The archipelagic sea lanes passage in special sea lanes is defined as the exercise of shipping and flight rights in accordance with the provisions of the Convention in the normal manner only for continuous, direct and as fast as possible transit ....."

In determining the sea lanes of the islands the Government of Indonesia refers to Article 18 above, as stated in Article 19 paragraph (1): ${ }^{7}$

“(1) ... The Government of Indonesia determines sea lanes, including flight routes above them, which are suitable for the exercise of the rights of archipelagic sea lanes crossings by foreign ships and aircraft as referred to in Article 18..."

In its implementation, Indonesia has not yet determined the archipelagic sea lane in accordance with the provisions of the 1982 KHL, particularly Article 53 paragraph (4) which has not accommodated all normal cross routes used for international shipping: ${ }^{8}$

“(4)... Such sea lanes and air routes shall transverse the archipelagic waters and adjacent territorial sea and shall include all normal passage routes used as routes for international navigations or overflight throught or over archipelagic water and ....."

In order to reduce the risk in terms of security in the Archipelago Waters, the determination of the archipelagic sea lanes by Indonesia has only determined three archipelagic sea lanes of the North-South route, and has not accommodated the sea lanes of the islands of the East-West route, this was considered by IMO as a partial determination. This situation becomes an opportunity for foreign ships to cross in these undetermined waters through normal routes normally used for international shipping in accordance with Article 53 paragraph (12) KHL 1982.

In the context of UNCLOS 1982 there are ironic rules related to state sovereignty, on the one hand the coastal states in Article 44 stipulate that, in this case an island nation, it is obliged not to impede (shall not

\footnotetext{
${ }^{1}$ Damos Dumoli Agusman. Hukum Perjanjian Internasional Kajian Teori dan Praktik Indonesia. (Bandung: Refika Aditama, 2014), p. 106.

2 Dhiana Puspitawati. Hukum Laut Internasional. (Jakarta: Kencana, 2017), p. 123.

${ }^{3}$ Martin Basiang, The Contemporary Law Dictionary Second Edition, "Mutatis Mutandis comes from Latin which means with changes as needed, or with the necessary changes in English" (Jakarta: Gramedia, 2016), p. 340.

${ }^{4}$ Dikdik Mohamad Sodik. Hukum Laut Internasional. (Bandung: Refika Aditama, 2011), p. 42.

${ }^{5}$ Kresno Buntoro. Alur Laut Kepulauan Indonesia (ALKI) Prospek dan Kendala. (Jakarta: Seskoal, 2012), p. 220.

${ }^{6}$ Article 18 paragraph (1) UNCLOS 1982.

${ }^{7}$ Ibid, Article 19 paragraph (1).

${ }^{8}$ Article 53 paragraph (4) UNCLOS 1982.
} 
hamper) the exercise of the rights of archipelagic sea lane crossings because this is part of international shipping , and is in the common interest of the international community. However, on the other hand, Article 49 paragraph (4) provides a guarantee that the rights of the archipelagic sea lanes will not affect the exercise of the sovereignty of the archipelago over archipelagic waters, airspace, the seabed and the land beneath. Isn't the limitation of the archipelago state in overseeing foreign vessels violating the rights of the archipelagic sea lanes is a result of the sovereignty of the archipelago itself?.

The potential threats that may arise from foreign ships passing through will certainly have an impact on the sovereignty of the Indonesian state, such as the Bawean Incident. ${ }^{1}$ In the perspective of the country's sovereignty especially the sovereignty of the sea at sea, the application of the right of passage for foreign ships in the archipelagic sea lanes must guarantee territorial integrity and to protect the wealth of the Indonesian state as an archipelagic country, according to the mandate in the 1957 Djuanda Declaration. conducted by Indonesia raises legal issues (legal issue), namely regarding the sea lanes of the islands that are not determined (does not designate) in PP Number 37 of 2002.

From the above exploration, the purpose of this study is to examine in more depth the regulation of the law and physiological review of the country's sovereignty related to foreign ship rights in the waters of the Indonesian Archipelago. As the most important aspect of this philosophy, the author will use three major themes of philosophy, namely the ontology aspect related to the nature of state sovereignty as the highest power possessed by a country, and from epistemological aspects of PP Number 37 of 2002 which can lead to legal uncertainty so that it will result in the axiological aspect of the state's goal is to organize the welfare and happiness of its people, or to hold a just and prosperous society. ${ }^{2}$

\section{Research Method}

This type of research is normative juridical research which is a process to find the rule of law, legal principles and legal doctrines in order to address the legal issues encountered. ${ }^{3}$ The research approach used is the statute approach. ${ }^{4}$ The legal material from normative research can be divided into two namely,

1. Primary legal materials, are legal materials that consist of legislation relating to foreign crossing rights including UNCLOS 1982, Law Number 17 of 1985, Law Number 6 of 1996, and PP Number 37 of 2002.

2. Secondary Legal Material, is supporting legal material from primary legal material, consisting of scientific work, research results or legal journals and legal dictionaries.

The technique of searching primary and secondary legal materials is carried out by studying literature and searching through the internet. ${ }^{5}$ The analysis technique in this research is to use analytic critique analysis technique in the form of a critical interpretation technique for legal materials, especially legislation materials. ${ }^{6}$

\section{Results and Discussion}

In order to find answers to the above problem formulation, the way taken is by legal philosophy that uses a philosophical approach to the sovereignty of the state in the waters of the archipelago. The philosophical review referred to here is to understand the sovereignty of the state in the waters of the archipelago from the perspective of legal philosophy, i.e.:

\section{Aspects of Ontology}

Basic ontology of state sovereignty is the basis of knowledge related to the object to be examined or the ultimate form of state sovereignty. Ontology discusses the fundamental nature of the existence of state sovereignty. UNCLOS 1982 regulates the sovereignty of coastal states in sea areas, namely in territorial seas and archipelagic waters. The conferring of rights by the Convention to a coastal state is a claim of a coastal state to the expansion of its authority in a sea territory. Compromise on this demand was then agreed that state

\footnotetext{
${ }^{1}$ Agus Supriatna. Beberapa Studi Kasus Terkait Air Defense yang Pernah Terjadi di Dunia dan Indonesia. Journal of the Indonesian Defense University, 2017.

${ }^{2}$ Soehino. Ilmu Negara. cetakan ke 9. (Yogyakarta: Liberty, 2013), p. 147.

${ }^{3}$ Marzuki, Peter Mahmud. Penelitian Hukum (Jakarta : Kencana Prenada Media, 2013), p.35.

${ }^{4}$ Ibid, p. 138 .

${ }^{5}$ Satjipto Rahadjo, Ilmu Hukum, (Bandung: Citra Aditya Bhakti, 2000), p. 255.

${ }^{6}$ Abdlatif and Hasbi Ali. Perihal Kaedah Hukum, (Bandung: Citra Aditya Bakti, 2010), p.9.
} 
sovereignty in the sea area was limited to territorial sea and archipelago waters. While outside the region, it remains an international territory, but the coastal state is given limited rights, powers and authority.

Related to the territorial sovereignty of Indonesia as an archipelagic country it should be noted that the sovereignty of an archipelagic state in archipelagic waters cannot be equated with inland waters, because archipelagic waters are a Sui Generis concept (Latin meaning there are no other comparable forms), according to Article 49 paragraph (3) must be carried out in accordance with the provisions of Chapter IV KHL 1982. Therefore, from the ontology aspect, the meaning of the country's sovereignty at sea is unlimited because it is limited by UNCLOS 1982.

The things that need to be considered from the provisions of Chapter IV above are that the exclusive authority of the island nation in the waters of the islands must be balanced with recognition of the rights of other countries. Therefore, recognition of the rights of other countries in the waters of the archipelago must still be considered by the island nation. First, the interests of other countries include that the island nation must respect the rights of other countries originating from existing agreements. Secondly, island nations must recognize the rights of traditional fisheries and other legal activities carried out by neighboring countries. Third, archipelagic countries must respect the shipping rights of other countries in their archipelago waters. In addition to paying attention to the granting of these rights, coastal countries also need to pay attention to the implications of vulnerability arising for the country's sovereignty over the granting of these rights.

\section{Aspects of Epistemology}

Epistemology is the object of the philosophy of law that specifically addresses the theory of science (theory of knowledge). ${ }^{1}$ Based on the understanding of the epistemology above, with regard to the sovereignty of the state at sea, the question that arises is: how did the sovereignty come from? Where did the term state sovereignty come from? what about the sovereignty of the country at sea? Is it true that the archipelagic sea lane that has not been determined by Indonesia will potentially endanger the country's sovereignty in the waters of the archipelago? The questions mentioned above arise as an effect of understanding epistemology, and as has been revealed in his theory, in epistemology that is affiliated with how we obtain knowledge, there are methods employed to obtain that knowledge.

In the context of the sovereignty of the Indonesian state, the internal sovereignty of the Indonesian state can be demonstrated by the shape and structure of the Indonesian state as an archipelago characterized by the archipelago as stipulated in Article 25A of the 1945 Constitution. Indonesia's external sovereignty can be demonstrated through various provisions contained in the 1945 Constitution and the regulations below . Articles 11 and 13 of the 1945 Constitution regulate Indonesia's relations with other countries regarding international agreements, appointment of ambassadors and consuls, and acceptance of ambassadors from other countries.

Next is the question of state sovereignty at sea. Provisions on archipelagic waters which are "sui generis", are the most essential elements of the provisions of Chapter IV KHL 1982. These provisions are a reflection of the compromise reached between differences in interests between island nations and maritime countries which are directly concerned with state principles islands, such as developed maritime countries in Western Europe that have an interest so that maritime traffic is not disrupted and large maritime countries that have military strategic interests, such as the United States and the Soviet Union. ${ }^{2}$

The legal status of archipelagic waters, airspace above archipelagic waters and the seabed and ground below are regulated in Article 49 KHL 1982, as follows:

a. That what is meant by archipelago waters is waters that are closed by archipelagic baselines, regardless of the depth or distance from the coast,

b. That the waters of the archipelago apply the sovereignty of the islands which are horizontal or vertical, including land, sea and air,

c. That state sovereignty in archipelagic waters is the same as in territorial sea, that is, it cannot apply absolute sovereignty as in land area,

d. Whereas in the waters of an archipelagic country there are rights of foreign ship crossing which must be respected and guaranteed to be carried out by an archipelagic state, namely the right of crossing the archipelagic sea lanes,

\footnotetext{
${ }^{1}$ Marzuki, Peter Mahmud. Penelitian Hukum (Jakarta : Kencana Prenada Media), p. 20.

${ }^{2}$ Mochtar Kusumaatmadja, ....Op.Cit., p. 63.
} 
e. That the archipelagic sea lane regime should not influence the status of the archipelago waters or the exercise of sovereignty by the island nation.

From the concrete explanation of the sovereignty of the state at sea above, it has automatically answered questions concerning the epistemological aspects of state sovereignty in the waters of the islands that have been proposed previously.

\section{Aspects of Axiology}

Axiology understands the law in terms of its benefits both legal pragmatism and benefit in terms of its substance. The axiology of law (the teaching of values, Waardenleer) plays a role in determining the content of values in law such as equality, freedom. ${ }^{1}$ An evaluation of something should always be measured by its use in achieving ultimate goals. Philosophy teaches and trains us to be broad-minded or not petty in looking at the world, at least we can pick values that can be used as measures. ${ }^{2}$

If axiology discusses the nature of values, then the opening question is what exactly is meant by value? Referring to Louis O. Kattsoff, actually the word "value" is a type word that includes all kinds of kindness and a number of other things. He continued, in short it could be said that the words "value" would have a variety of meanings as shown in the following examples:

a. Contain value (meaning useful).

b. Is a value (meaning good or true or beautiful).

c. Having a value (meaning being an object of desire, having qualities that can cause people to take an "approve" attitude or have a certain nature of values).

d. Give value (meaning responding to something as desired or as something that describes a particular value).

In connection with the sovereignty of the state, it is the understanding of values objectively and subjectively that will be used to look for the values contained in state sovereignty. Thus, referring to the understanding of these values, the question that arises is what are the views of people/society objectively and subjectively of the sovereignty of the state?, or how do people judge the sovereignty of the state? and the main thing is what are the values contained in state sovereignty?

To see people's views of the values contained in state sovereignty, it can be seen from the opinions or definitions given by these people towards state sovereignty. The people referred to here are legal experts. The following will mention some of the views or definitions in question:

a. That sovereignty is the supreme power to determine the law in a single, original, eternal and indivisible State (Jean Bodin). ${ }^{3}$

b. Sovereignty is a concept of power, that is, the scope of power and the domain of power. In this connection, the approach is used to analyze the idea of sovereignty concerning the matter of activities or activities that are included in the sovereign function. While the reach of sovereignty is related to who is the subject and holder of sovereignty (Jack H. Nagel). ${ }^{4}$

c. A person or body or head of state who has sovereignty can make positive laws that will be applied to members of an independent political community under the authority of the sovereignty. In this case, the majority of the community will obey the will of the sovereignty (John Austin). ${ }^{5}$

d. The highest power which contains two important constraints in itself, namely that power is on the boundaries of the territory of the country that has that power, and sovereignty does not end when the power of another country begins. ${ }^{1}$

${ }^{1}$ Dewa Gede Atmadja. Filsafat Hukum Dimensi Tematis dan Historis. (Malang: Setara Pers, 2013), p. 12.

${ }^{2}$ Driyarkara. Karya Lengkap Driyarkara Esai-esai Filsafat Pemikir yang terlibat penuh dalam perjuangan bangsanya, edited by A. Sudiarja SJ et al, (Jakarta: PT. Gramedia Pustaka Utama, 2006), p.1026-102.

${ }^{3}$ Soehino, Op. Cit., p. 151.

${ }^{4}$ Ibid.

${ }^{5}$ Ibid. 
Diverse understanding of state sovereignty, but in essence the legal experts have the same basic view that is that between countries have or have the values of equality or equality of sovereignty (equality before sovereign state). This principle is very broad meaning, in this principle contained the value of sovereignty, the value of integrity, the value of mutual respect and political, economic, social and cultural values. The next review is to find the value contained in the sovereignty of the country at sea based on the assessment of the state through legislation. The following "assessment" of state sovereignty by the laws and regulations in question:

a. Law Number 17 of 1985 concerning Ratification of the United Nations Convention on the Law of the Sea.

Even though foreign ships and aircraft enjoy the rights of the archipelagic sea lanes passage through the sea lanes and flight routes, this in other fields than shipping and aviation may not reduce the island's sovereignty over the water and airspace above it, the seabed and the land beneath it and the source of wealth nature in it (explanation of the law).

b. Law Number 6 of 1996 concerning Indonesian Waters.

All waters around, between, and connecting islands or parts of islands which are included in the mainland of the Republic of Indonesia, not taking into account their width or width are an integral part of the mainland territory of the Republic of Indonesia so that they are part of Indonesian waters that are under state sovereignty Republic of Indonesia (Article 2 paragraph 2).

c. Government Regulation Number 37 of 2002 concerning the Rights and Obligations of Foreign Vessels and Aircraft in Implementing the Rights of the Islands Sea Pathways through the Specified Islands Sea Paths.

This Government Regulation is an implementing regulation of Law Number 6 of 1996 concerning Indonesian Waters. Related to state sovereignty regulated in article 4 paragraph (3) that foreign ships and aircraft when exercising the right of archipelagic sea lanes may not threaten or use violence against sovereignty, territorial integrity, or political independence of the Republic of Indonesia, or in any other way that violates the principles of international law contained in the Charter of the United Nations.

As for the assessment of the Government of the Republic of Indonesia through the legislation mentioned above, the country's sovereignty contains values (meaning useful), as follows: ${ }^{2}$

a. The value of unity, territorial integrity and integrity,

b. The value of security defense,

c. The value of mutual respect between countries,

d. The value of the country's goals and objectives,

e. Political, economic, socio-cultural and historical values.

Thus the analysis of the philosophical review of state sovereignty through approaches to aspects of ontology, epistemology and axiology, that state sovereignty in the waters of the archipelago does "exist" and every island nation has it with unlimited state power, including the Unitary State of the Republic of Indonesia.

\section{Conclusions}

1. Regarding PP No. 37/2002, the sovereignty of Indonesia as an archipelagic state needs to be noted that the meaning of the sovereignty of an archipelagic state in archipelagic waters cannot be equated with in territorial sea, because archipelagic waters are a Sui Generis concept, which according to Article 49 paragraph (3) must be carried out in accordance with the provisions of Chapter IV KHL 1982, so that the determination of the archipelagic sea lane should refer to Law Number 6 of 1996 and Article 53 of UNCLOS 1982.

2. Philosophical review of State sovereignty,

a. The ontology aspect of sovereignty as the highest power of a country in international law has undergone a shift, international law views sovereignty in the sense of supreme supreme power can no longer be maintained, because of the rapid international relations at this time, moreover the international community is in the era of

\footnotetext{
${ }^{1}$ Mochtar Kusumaatmadja dan Etty R. Agoes, Op. Cit., p. 136.

${ }^{2}$ Mahendra Putra Kurnia. Hukum Kewilayahan Indonesia. (Malang: Universitas Brawijaya Press, 2011), p. 74.
} 
globalization. The highest power has shifted to a more limited direction, namely only within the national borders, while to get out of national borders is given and limited by international law. Therefore, the meaning of the nature of state sovereignty at sea according to UNCLOS 1982 is interpreted as unlimited state power because of the existence of the rights of the archipelagic sea lanes for foreign vessels in the waters of the Indonesian Archipelago.

b. The epistemological aspect of sovereignty for a country is related to the issue of the origin or theory of sovereignty. State sovereignty in the archipelago waters is the same as in the territorial sea, that is, it cannot apply absolute sovereignty like those in the land area or in the air. Determination of ALKI will partly complicate the supervision of foreign vessels in unspecified sea lanes. This raises vulnerability for the sovereignty of the Indonesian state. The vulnerability will multiply on routes normally used for international shipping, if ALKI East-West routes in the Java Sea have not been determined.

c. The axiological aspect of state sovereignty is to bring benefits to create order and legal certainty related to the issue of the rights of foreign ships and aircraft crossing over vast waters based on the rights of archipelagic sea lanes crossing. In the perspective of the country's sovereignty especially the sovereignty of the state at sea, the determination of the right of passage for foreign vessels in the archipelagic sea lanes must guarantee territorial integrity and aim at protecting the wealth of the Indonesian state as an archipelago, according to the values contained in the 1957 Djuanda Declaration.

\section{Reference}

Abdlatif and Hasbi Ali. Perihal Kaedah Hukum, (Bandung: Citra Aditya Bakti, 2010).

Agus Supriatna. Beberapa Studi Kasus Terkait Air Defense yang Pernah Terjadi di Dunia dan Indonesia. Journal of the Indonesian Defense University, 2017.

Damos Dumoli Agusman. Hukum Perjanjian Internasional Kajian Teori dan Praktik Indonesia. (Bandung: Refika Aditama, 2014).

Dewa Gede Atmadja. Filsafat Hukum Dimensi Tematis dan Historis. (Malang: Setara Pers, 2013).

Dhiana Puspitawati. Hukum Laut Internasional. (Jakarta: Kencana, 2017).

Dikdik Mohamad Sodik. Hukum Laut Internasional. (Bandung: Refika Aditama, 2011).

Driyarkara. Karya Lengkap Driyarkara Esai-esai Filsafat Pemikir yang terlibat penuh dalam perjuangan bangsanya, edited by A. Sudiarja SJ et al, (Jakarta: PT. Gramedia Pustaka Utama, 2006).

Etty R. Agoes. Konvensi Hukum Laut 1982, Masalah Pengaturan Hak Lintas Kapal Asing. (Bandung: Abardin, 1991).

Hikmahanto Juwana. Konsekuensi Keikutsertaan Indonesia Dalam Perjanjian Internasional, Chandra Motik Yusuf (Ed), Negara Kepulauan Menuju Negara Maritim. (Jakarta: Lembaga Laut Indonesia, 2010).

Indien Winarwati. Konsep Negara Kepulauan, Perspektif Hukum Laut dan Penetapan Garis Batas Negara. (Malang: Setara Press, 2016).

Kresno Buntoro. Alur Laut Kepulauan Indonesia (ALKI) Prospek dan Kendala. (Jakarta: Seskoal, 2012).

Mahendra Putra Kurnia. Hukum Kewilayahan Indonesia. (Malang: Universitas Brawijaya Press, 2011).

Martin Basiang, The Contemporary Law Dictionary Second Edition, "Mutatis Mutandis comes from Latin which means with changes as needed, or with the necessary changes in English" (Jakarta: Gramedia, 2016).

Marzuki, Peter Mahmud. Penelitian Hukum (Jakarta : Kencana Prenada Media, 2013).

Mochtar Kusumaatmadja. Hukum Laut Internasional. (Bandung: Bina Cipta, 1986).

Satjipto Rahadjo. Ilmu Hukum. (Bandung: Citra Aditya Bhakti, 2000).

Soehino. Ilmu Negara. 9th print. (Yogyakarta: Liberty, 2013).

\section{Laws And Regulations}

Dutch East Indies Staatsblad No. 442 of 1939 concerning Territorial Sea and Maritime Environments (Territoriale Zee en Maritieme Kringen Ordonnansi).

Indonesia, The 1945 Constitution of the Republic of Indonesia. 
Indonesia, General Explanation Government Regulation of the Republic of Indonesia Number 37 of 2002 concerning the Rights and Obligations of Foreign Vessels and Aircraft in Implementing the Rights of the Islands Sea Channel Through the Specified Islands Sea Channel. Republic of Indonesia State Gazette Number 71 of 2002. Additional State Gazette Number 4210.

Indonesia, Law Number 6 of 1996 concerning Indonesian Waters. Republic of Indonesia State Gazette Number 73 of 1996, Supplement to State Gazette Number 3647.

Indonesia, Law Number 17 Year 1985 Concerning Ratification of the United Nations Convention on the Law of the Sea (United Nations Convention on the Law of the Sea). Statute Book Number 76, 1985, Supplement to Statute Book Number 3319.

Indonesia, Government Announcement on the Territory of the Republic of Indonesia on 13 December 1957.

Indonesia, Memorandum of Understanding between the Geospatial Information Agency (BIG), the Navy's Oceanographic Hydro Center and the Maritime Coordinating Ministry on August 10, 2018.

United Nations Convention on the Law of the Sea (UNCLOS) 1982. 